\title{
Bioremoval of the synthetic dye malachite green by marine Trichoderma $\mathrm{sp}$
}

\author{
Kandasamy Saravanakumar and Kandasamy Kathiresan*
}

\begin{abstract}
In the present study, a marine strain of Trichoderma sp was used for degradation of a synthetic dye, malachite green. Individual and interaction effects of the physical and chemical factors that influenced the percentage of dye degradation were tested by response surface methodology. For optimization, enzyme production and dye degradation were assessed under different temperatures $\left(5-40^{\circ} \mathrm{C}\right)$, $\mathrm{pH}$ values $(3-11)$, yeast extract $\left(5-9 \mathrm{~g} \mathrm{~L}^{-1}\right)$ and incubation period ( $0-15$ days). The optimum conditions found for dye degradation, were $30^{\circ} \mathrm{C}, \mathrm{pH} 5.8,5.81 \mathrm{mg} \mathrm{L}{ }^{-1}$ yeast extract for an incubation period of 10 days. Whereas for laccase production they were $29^{\circ} \mathrm{C}, \mathrm{pH}_{5.3,7.7} \mathrm{mg} \mathrm{L}^{-1}$ yeast extract for an incubation period of 12 days. It was confirmed that laccase production required the higher nitrogen source. Degradation of dye was confirmed by using analytical techniques such as FTIR, UV-Vis spectral and scanning electron microscope analysis. Furthermore, toxicity effect of degraded and undegraded dye solutions was tested with Artemia salina. Hundred percent mortality was observed in undegraded dye solution as against only 2-5\% in degraded dye solution. This work proved the potential of marine strain of Trichoderma Hypocrea lixii on dye degradation.
\end{abstract}

Keywords: Marine Trichoderma; Hypocrea lixii; Mangroves; Malachite green; FTIR; SEM

\section{Introduction}

Textile synthetic dyes have stable and toxic molecules. They affect biological systems by inducing mutations and causing cancer, when they are discharged in to the water bodies. Many methods are used for dye removal, they includephysical/chemical adsorption, oxidation, biological treatments (Akar et al. 2013), microbial biomass and enzyme treatments (Anjaneyulu et al. 2005). Among these, biological treatment methods especially using microbial enzymes are highly efficient for dye degradation (PeraltaHernandez et al. 2009; Baldeva et al. 2013). Azo/synthetic dyes contain aromatic and phenolic compounds. Degradation of these compounds in azo dyes is a challenge in current research. Microbial enzymes are capable of removing phenolics and aromatic amines present in the azo dyes (Claus 2003; Casas et al. 2007). The enzyme laccase, has enormous biotechnological applications such as in paper pulp bleaching, decolorization of synthetic dyes, wine clarification, fruit juice processing, bioremediation, ethanol production, biosensors, biofuel cells, organic synthesis and drug synthesis (Mayer and Staples 2002; Hadzhiyska et al. 2006; Zhu et al. 2011). Generally

\footnotetext{
* Correspondence: saravana732@gmail.com

Centre of Advanced Study in Marine Biology, Faculty of Marine Sciences, Annamalai University, Parangipettai 608502, Tamil Nadu, India
}

industrial dyes are highly tolerant to light, temperature, oxidization. Hence enzymatic degradation is preferable over physicochemical methods of dye degradation (Niladevi and Prema 2008). Microbial enzymes have been studied mostly for terrestrial fungal strains in dye degradation (Shubo Deng et al. 2005). They are economical and can be applied to a wide range of dyes degradation process (McMullan, et al. 2001; Robinson et al. 2001; Saparrat and Hammer 2006; Xiangkang et al. 2011). Such a study in marine strains is largely wanting. Hence the present study was undertaken with the objectives of optimizing conditions required for the laccase production by T. harzianum/ Hypocrea lixii TSK8 and also enzymatic degradation of synthetic dye by using statistical method.

\section{Materials and methods Chemicals}

All the chemicals including Malachite Green were purchased from Himedia, Merck and Sigma, India.

\section{Preparation of dye solution}

Stock solution of Malachite Green was prepared by dissolving the dye in distilled water to concentrations of $100-250 \mathrm{mgL}^{-1}$. $250 \mathrm{mg} \mathrm{L}^{-1}$ of dye solution is equivalent to $100 \%$ of Malachite Green.

\section{苜}




\section{Culture conditions and culture identification}

The fungus T. harzianum/Hypocrealixii TSK8 (JQ809340) isolated from mangroves was used for this experiment. The identity of the fungal strain was confirmed based on $18 \mathrm{~S}$ rRNA sequence in comparison with that available in NCBI database by using BLAST methods. This strain was stored on potato dextrose agar (PDA) slants at $4^{\circ} \mathrm{C}$ for the further experiments (Saravanakumar et al. 2013).

\section{Laccase production and dye degradation}

Laccase production and dye degradation experiments were carried out in 30 runs using central composite design of the response surface methodology. This experimental design is presented in Table 1 along with experimental and predicted values of response. All these conditions of the experiment were carried out in $500 \mathrm{~mL}$ Erlenmeyer flasks. Each flask contained $100 \mathrm{~mL}$ of a medium consisted of $\mathrm{MgSO}_{4}(0.1 \mathrm{~g}),\left(\mathrm{NH}_{4}\right)_{2} \mathrm{SO}_{4}(0.6 \mathrm{~g}), \mathrm{NaCl}(0.5 \mathrm{~g}), \mathrm{K}_{2} \mathrm{HPO}_{4}$ (1.36 g), $\mathrm{CaCl}_{2}(0.02 \mathrm{~g}), \mathrm{MnSO}_{4}(1.1 \mathrm{~g}), \mathrm{ZnSO}_{4}(0.2 \mathrm{~g})$, $\mathrm{CuSO}_{4}(0.2 \mathrm{~g})$ and $\mathrm{FeSO}_{4}(0.14 \mathrm{~g})$ in $1000 \mathrm{~mL}$ of $50 \%$ seawater and $750 \mathrm{ppm}$ of malachite green. The fungal strain of Hypocrea was cultivated in the potato dextrose agar medium in a Petri plate at $30^{\circ} \mathrm{C}$ for $5-10$ days. The agar plugs of $8 \mathrm{~mm}$ diameter were cut and used as inoculum for laccase production and dye degradation under different temperatures $\left(5-40^{\circ} \mathrm{C}\right)$, $\mathrm{pH}$ levels $(3,5,7,9$ and 11$)$, yeast extract $\left(5-9 \mathrm{gL}^{-1}\right)$ and incubation period $(0-15$ days). The quadratic model equation (Box and Behnken

Table 1 Experimental design (CCD) of response surface methodology

\begin{tabular}{|c|c|c|c|c|c|c|c|c|}
\hline \multirow[t]{2}{*}{ Std runs } & \multirow[t]{2}{*}{ (A) temperature $\left({ }^{\circ} \mathrm{C}\right)$} & \multirow[t]{2}{*}{ (B) $\mathrm{pH}$} & \multirow{2}{*}{$\begin{array}{c}(\mathrm{C}) \text { yeast } \\
\text { extract }\left(\mathrm{g} \mathrm{L}^{-1}\right)\end{array}$} & \multirow{2}{*}{$\begin{array}{l}\text { (D) incubation } \\
\text { period (days) }\end{array}$} & \multicolumn{2}{|c|}{$\%$ of dye degradation } & \multicolumn{2}{|c|}{ Laccase production $\left(\mathrm{UmL}^{-1}\right)$} \\
\hline & & & & & Experimental & Predicted & Experimental & Predicted \\
\hline 1.0 & 10.0 & 3.0 & 5.0 & 0.0 & 0.20 & 0.82 & 0.02 & 0.22 \\
\hline 2.0 & 40.0 & 3.0 & 5.0 & 0.0 & 1.50 & 2.61 & 0.03 & 0.11 \\
\hline 3.0 & 10.0 & 11.0 & 5.0 & 0.0 & 1.60 & 2.23 & 0.02 & 0.14 \\
\hline 4.0 & 40.0 & 11.0 & 5.0 & 0.0 & 1.20 & 4.43 & 0.01 & 0.22 \\
\hline 5.0 & 10.0 & 3.0 & 9.0 & 0.0 & 0.20 & 0.44 & 0.20 & 0.15 \\
\hline 6.0 & 40.0 & 3.0 & 9.0 & 0.0 & 1.20 & 2.77 & 0.32 & 0.05 \\
\hline 7.0 & 10.0 & 11.0 & 9.0 & 0.0 & 1.20 & 2.14 & 0.01 & 0.05 \\
\hline 8.0 & 40.0 & 11.0 & 9.0 & 0.0 & 3.50 & 4.87 & 0.02 & 0.66 \\
\hline 9.0 & 10.0 & 3.0 & 5.0 & 15.0 & 87.71 & 93.26 & 2.71 & 2.85 \\
\hline 10.0 & 40.0 & 3.0 & 5.0 & 15.0 & 87.01 & 94.76 & 2.01 & 2.23 \\
\hline 11.0 & 10.0 & 11.0 & 5.0 & 15.0 & 87.74 & 94.87 & 2.74 & 2.97 \\
\hline 12.0 & 40.0 & 11.0 & 5.0 & 15.0 & 86.80 & 96.78 & 1.80 & 2.76 \\
\hline 13.0 & 10.0 & 3.0 & 9.0 & 15.0 & 87.15 & 92.61 & 2.15 & 2.20 \\
\hline 14.0 & 40.0 & 3.0 & 9.0 & 15.0 & 86.45 & 94.64 & 1.45 & 2.11 \\
\hline 15.0 & 10.0 & 11.0 & 9.0 & 15.0 & 86.70 & 94.50 & 1.70 & 2.61 \\
\hline 16.0 & 40.0 & 11.0 & 9.0 & 15.0 & 87.87 & 96.94 & 2.87 & 2.92 \\
\hline 17.0 & 5.0 & 7.0 & 7.0 & 7.5 & 88.39 & 78.25 & 3.39 & 2.92 \\
\hline 18.0 & 55.0 & 7.0 & 7.0 & 7.5 & 88.45 & 72.64 & 3.45 & 2.58 \\
\hline 19.0 & 25.0 & 1.0 & 7.0 & 7.5 & 86.54 & 76.42 & 1.54 & 1.53 \\
\hline 20.0 & 25.0 & 15.0 & 7.0 & 7.5 & 87.17 & 72.55 & 2.17 & 1.10 \\
\hline 21.0 & 25.0 & 7.0 & 3.0 & 7.5 & 88.99 & 78.89 & 3.99 & 3.51 \\
\hline 22.0 & 25.0 & 7.0 & 11.0 & 7.5 & 88.89 & 78.67 & 3.89 & 3.29 \\
\hline 23.0 & 25.0 & 7.0 & 7.0 & 7.5 & 87.55 & 86.98 & 2.55 & 3.19 \\
\hline 24.0 & 25.0 & 7.0 & 7.0 & 22.5 & 87.24 & 66.93 & 2.24 & 1.16 \\
\hline 25.0 & 25.0 & 7.0 & 7.0 & 7.5 & 88.90 & 86.98 & 3.90 & 3.19 \\
\hline 26.0 & 25.0 & 7.0 & 7.0 & 7.5 & 88.90 & 86.98 & 3.90 & 3.19 \\
\hline 27.0 & 25.0 & 7.0 & 7.0 & 7.5 & 88.90 & 86.98 & 3.90 & 3.19 \\
\hline 28.0 & 25.0 & 7.0 & 7.0 & 7.5 & 88.90 & 86.98 & 3.90 & 3.19 \\
\hline 29.0 & 25.0 & 7.0 & 7.0 & 7.5 & 88.90 & 86.98 & 3.90 & 3.19 \\
\hline 30.0 & 25.0 & 7.0 & 7.0 & 7.5 & 86.74 & 86.98 & 1.74 & 3.19 \\
\hline
\end{tabular}


1960) was used to evaluate the interaction and individual relationships of the factors on the responses of (Y1) \% of dye decolouration and (Y2) laccase production $\left(\mathrm{UmL}^{-1}\right)$ and the independent variables: X1 (temperature), X2 (pH), X3 (yeast extract) and X4 (incubation period).

\section{Statistical optimization of the experimental conditions}

The data obtained from RSM on dye degradation and enzyme production were subjected to analysis of variance (ANOVA). The experimental results of RSM were fit via the response surface regression procedure, by following second order polynomial equation.

$$
Y i=\beta_{0}+\Sigma_{i} \beta_{i} X_{i}+\Sigma_{i} \beta_{i i} X_{i}^{2}+\Sigma_{i j} \beta_{i j} X_{i} X_{j}
$$

Where $\mathrm{Yi}$ is the predicted response, $\mathrm{X}_{\mathrm{i}} \mathrm{X}_{\mathrm{j}}$ are independent variables, $\beta_{0}$ is the offset term, $\beta_{\mathrm{i}}$ is the $\mathrm{i}^{\text {th }}$ linear coefficient, $\beta \mathrm{ii}$ is the $\mathrm{i}^{\text {th }}$ quadratic coefficient, and $\beta_{\mathrm{ij}}$ is the $\mathrm{ij}^{\text {th }}$ interaction coefficient. However, in this experiment, the independent variables were coded as $\mathrm{X}_{1}, \mathrm{X}_{2}, \mathrm{X}_{3}$ and $\mathrm{X}_{4}$. Thus, the second order polynomial equation can be presented as follows.

$$
\begin{aligned}
\text { Y1 (Dye degradation \%) }= & \beta_{0}+\beta_{1} X_{1}+\beta_{2} X_{2}+\beta_{3} X_{3} \\
& +\beta_{4} X_{4}+\beta_{11} X_{1}^{2}+\beta_{22} X_{2}^{2} \\
& +\beta_{33} X_{3}^{2}+\beta_{44} X_{4}^{2}+\beta_{12} X_{1} X_{2} \\
& +\beta_{13} X_{1} X_{3}+\beta_{14} X_{1} X_{4} \\
& +\beta_{23} X_{2} X_{3}+\beta_{24} X_{2} X_{4} \\
& +\beta_{34} X_{3} X_{4}
\end{aligned}
$$

$$
\begin{aligned}
\text { Y2 (laccase UmL } & -1)= \\
& \beta_{0}+\beta_{1} \mathrm{X}_{1}+\beta_{2} \mathrm{X}_{2}+\beta_{3} \mathrm{X}_{3} \\
& +\beta_{4} \mathrm{X}_{4}+\beta_{11} \mathrm{X}_{1}^{2}+\beta_{22} \mathrm{X}_{2}^{2}+\beta_{33} \mathrm{X}_{3}^{2} \\
& +\beta_{44} \mathrm{X}_{4}^{2}+\beta_{12} \mathrm{X}_{1} \mathrm{X}_{2}+\beta_{13} \mathrm{X}_{1} \mathrm{X}_{3} \\
& +\beta_{14} \mathrm{X}_{1} \mathrm{X}_{4}+\beta_{23} \mathrm{X}_{2} \mathrm{X}_{3}+\beta_{24} \mathrm{X}_{2} \mathrm{X}_{4} \\
& +\beta_{34} \mathrm{X}_{3} \mathrm{X}_{4}
\end{aligned}
$$

Whereas: $\mathrm{X}_{1}$ is temperature $\left(10-40^{\circ} \mathrm{C}\right), \mathrm{X}_{2}$ is $\mathrm{pH}$ levels $(3,5,7,9$ and 11$), X_{3}$ is yeast extract $\left(5-9 \mathrm{gL}^{-1}\right)$, and $\mathrm{X}_{4}$ is incubation period (0-15days).

Statistical software namely the Design expert (8.0.6 package) was used for the regression analysis and to plot the response surface graphs of the experimental data.

\section{Analysis of dye decolouration and degradation}

Five $\mathrm{mL}$ of culture filtrate from each group of flasks was drawn and centrifuged at 3,000 rpm for $60 \mathrm{~min}$ at $4^{\circ} \mathrm{C}$ temperature. After centrifugation, the supernatant was collected and the absorbance was determined at $640 \mathrm{~nm}$ using a spectrophotometer (Elico, Model 301). This was done according to the experimental setup derived from central composite design of response surface methodology. The change of absorbance value was converted into concentration of dye value for determining the degradation of Malachite Green dye. The percentage of decolouration was calculated according to the following formula (Ayed et al. 2010, 2011).

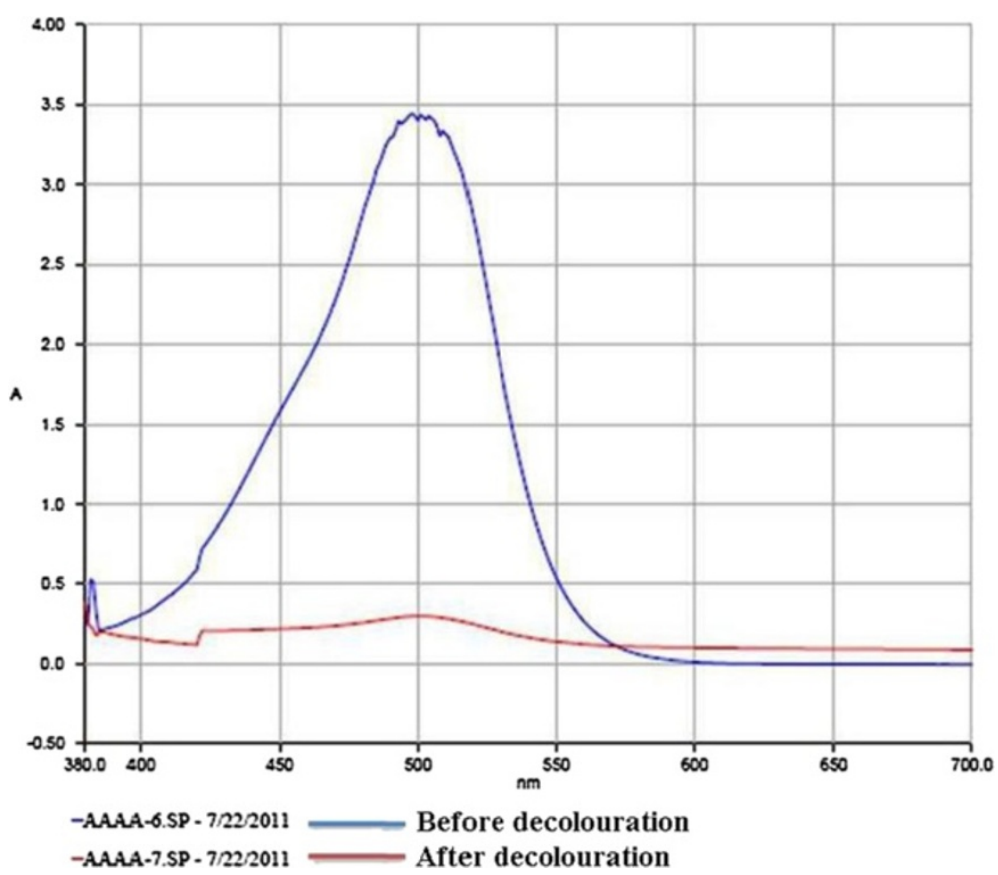

Figure 1 Effects of Hypocrea lixii on dye decolouration (a) conical flasks; (b) UV- absorption spectrum. 
Table 2 Analysis of variance table (ANOVA) for response surface methodology of main effects and interacting effects of parameters in quadratic model for the dye degradation by Hypocrea lixii

\begin{tabular}{|c|c|c|c|c|c|}
\hline Source & Sum of squares & df & Mean square & F value & p-value Prob $>F$ \\
\hline$\overline{\text { Model }}$ & 42482.83 & 14 & 3034.488 & 20.09046 & $<0.0001^{* * *}$ \\
\hline $\mathrm{X}_{1}$-Temperature $\left({ }^{\circ} \mathrm{C}\right)$ & 22.77126 & 1 & 22.77126 & 0.150762 & $0.7033^{\mathrm{NS}}$ \\
\hline $\mathrm{X}_{2}-\mathrm{pH}$ & 18.41882 & 1 & 18.41882 & 0.121946 & $0.007318^{* *}$ \\
\hline $\mathrm{X}_{3}$-Yeast extract $\left(\mathrm{g} \mathrm{L}^{-1}\right)$ & 0.069738 & 1 & 0.069738 & 0.000462 & $0.9831^{\mathrm{NS}}$ \\
\hline $\mathrm{X}_{4}$-Incubation period (days) & 36055.94 & 1 & 36055.94 & 238.7159 & $<0.0001^{* * *}$ \\
\hline$x_{1} x_{2}$ & 0.16657 & 1 & 0.16657 & 0.001103 & $0.009739^{* *}$ \\
\hline$x_{1} x_{3}$ & 0.278689 & 1 & 0.278689 & 0.001845 & $0.9663^{\mathrm{NS}}$ \\
\hline$x_{1} x_{4}$ & 0.085404 & 1 & 0.085404 & 0.000565 & $0.9813^{N S}$ \\
\hline$x_{2} x_{3}$ & 0.081467 & 1 & 0.081467 & 0.000539 & $0.009818^{* *}$ \\
\hline$X_{2} X_{4}$ & 0.040612 & 1 & 0.040612 & 0.000269 & $0.9871^{\mathrm{NS}}$ \\
\hline$X_{3} X_{4}$ & 0.075826 & 1 & 0.075826 & 0.000502 & $0.9824^{\mathrm{NS}}$ \\
\hline$x_{1}^{2}$ & 298.9977 & 1 & 298.9977 & 1.979577 & $0.1798^{\mathrm{NS}}$ \\
\hline$x_{2}^{2}$ & 320.0991 & 1 & 320.0991 & 2.119283 & $0.1661^{\mathrm{NS}}$ \\
\hline$x_{3}^{2}$ & 118.8562 & 1 & 118.8562 & 0.786912 & $0.3890^{\mathrm{NS}}$ \\
\hline$x_{4}^{2}$ & 12614.69 & 1 & 12614.69 & 83.51817 & $<0.0001^{* * *}$ \\
\hline Residual & 2265.618 & 15 & 151.0412 & & \\
\hline Lack of Fit & 1851.681 & 9 & 205.7423 & 2.982222 & $0.0984^{\mathrm{NS}}$ \\
\hline Pure Error & 413.9376 & 6 & 68.9896 & & \\
\hline Cor Total & 44748.45 & 29 & & & \\
\hline
\end{tabular}

Statistically significant ***(P<0.0001), **(P<0.01), NS Non-significant.

Table 3 Analysis of variance table (ANOVA) for response surface methodology of main effects and interacting effects of parameters in quadratic model for the laccase production by Hypocrea lixii

\begin{tabular}{|c|c|c|c|c|c|}
\hline Source & Sum of squares & df & Mean & F value & $\mathrm{p}$-value Prob $>\mathrm{F}$ \\
\hline Model & 48.56277 & 14 & 3.468769 & 2.621997 & $0.0371^{*}$ \\
\hline $\mathrm{X}_{1}$-Temperature $\left({ }^{\circ} \mathrm{C}\right)$ & 0.000179 & 1 & 0.000179 & 0.000136 & $0.0009^{* * *}$ \\
\hline $\mathrm{X}_{2}-\mathrm{pH}$ & 0.717105 & 1 & 0.717105 & 0.54205 & $0.00729^{* *}$ \\
\hline $\mathrm{X}_{3}$-Yeast extract $\left(\mathrm{g} \mathrm{L}^{-1}\right)$ & 0.069738 & 1 & 0.069738 & 0.052714 & $0.8215^{\mathrm{NS}}$ \\
\hline $\mathrm{X}_{4}$-Incubation period (days) & 25.37625 & 1 & 25.37625 & 19.18158 & $0.0005^{* * *}$ \\
\hline$x_{1} x_{2}$ & 0.16657 & 1 & 0.16657 & 0.125908 & $0.7277^{\mathrm{NS}}$ \\
\hline$x_{1} x_{3}$ & 0.278689 & 1 & 0.278689 & 0.210657 & $0.6528^{\mathrm{NS}}$ \\
\hline$x_{1} x_{4}$ & 0.085404 & 1 & 0.085404 & 0.064556 & $0.8029^{N S}$ \\
\hline$x_{2} x_{3}$ & 0.081467 & 1 & 0.081467 & 0.06158 & $0.8074^{N S}$ \\
\hline$x_{2} X_{4}$ & 0.040612 & 1 & 0.040612 & 0.030698 & 0.8633 NS \\
\hline$x_{3} X_{4}$ & 0.075826 & 1 & 0.075826 & 0.057316 & $0.8140^{N S}$ \\
\hline$x_{1}^{2}$ & 0.395835 & 1 & 0.395835 & 0.299206 & $0.5924^{N S}$ \\
\hline$x_{2}^{2}$ & 7.268732 & 1 & 7.268732 & 5.494339 & $0.0333^{*}$ \\
\hline$x_{3}^{2}$ & 0.080502 & 1 & 0.080502 & 0.06085 & $0.8085^{N S}$ \\
\hline$x_{4}^{2}$ & 19.98253 & 1 & 19.98253 & 15.10453 & $0.0015^{* *}$ \\
\hline Residual & 19.84424 & 15 & 1.322949 & & \\
\hline Lack of Fit & 6.769842 & 9 & 0.752205 & 0.345196 & $0.9261^{\mathrm{NS}}$ \\
\hline Pure Error & 13.0744 & 6 & 2.179066 & & \\
\hline Cor Total & 68.40701 & 29 & & & \\
\hline
\end{tabular}

Statistically significant ${ }^{* *}(P<0.0001),{ }^{* *}(P<0.01),{ }^{*}(P<0.05)$, NS Non-significant. 


$$
\% \text { Decolourisation }=\frac{(\mathrm{I}-\mathrm{F})}{\mathrm{I}} \times 100
$$

Where

$I$ was the initial absorbance and

$F$ the absorbance at incubation time $t$

\section{FT-IR analysis}

Fourier Transform Infrared (FT-IR) spectroscopy was performed for testing the degradation products present in the degraded dye samples. For FT-IR analysis, biological treatment process was performed with $250 \mathrm{~mL}$ solution containing $25 \mathrm{mgL}^{-1}$ of malachite green and $5 \mathrm{~mL}$ of Hypocrea lixii biomass. At the reaction times of $0 \mathrm{~h}$ (control) and 24 days, samples were drawn to get degradation products, extracted in $30 \mathrm{~mL}$ of diethyl ether, crystallized and then used for FTIR analysis (Ayed et al. 2010).

\section{Enzyme assays}

Laccase activity was determined in a reaction mixture $(2.0 \mathrm{~mL})$ containing $1.7 \mathrm{~mL}$ sodium acetate buffer $(20 \mathrm{mM}$, $\mathrm{pH} 4.0)$ at room temperature $\left(25^{\circ} \mathrm{C}\right)$, then observed at $420 \mathrm{~nm}$. The reaction was started by adding $0.2 \mathrm{~mL}$ of laccase solution (Telke et al. 2009). Laccase activity ( $\mathrm{UmL}^{-1}$ ) was defined as the amount of enzyme requiredto oxidize $1 \mu \mathrm{M}$ of $o$-tolidine per minute. Protein concentration was measured by the Lowry method (Lowry et al. 1951) using bovine serum albumin as the standard. All of the measurements were performed in triplicate.

\section{Molecular weight determination of laccase}

Purification of laccase was done by the method proposed by Zhang et al. (2010). The culture filtrate was fractionated by ammonium sulphate precipitation and dialyzed at $4^{\circ} \mathrm{C}$ in $20 \mathrm{mM}$ sodium acetate buffer ( $\left.\mathrm{pH} 4.8\right)$. The purity and molecular mass of the purified laccase was determined by SDS-PAGE using a 5\% stacking gel and a $12 \%$ resolving gel and this was followed by staining with Coomassie brilliant blue R-250.
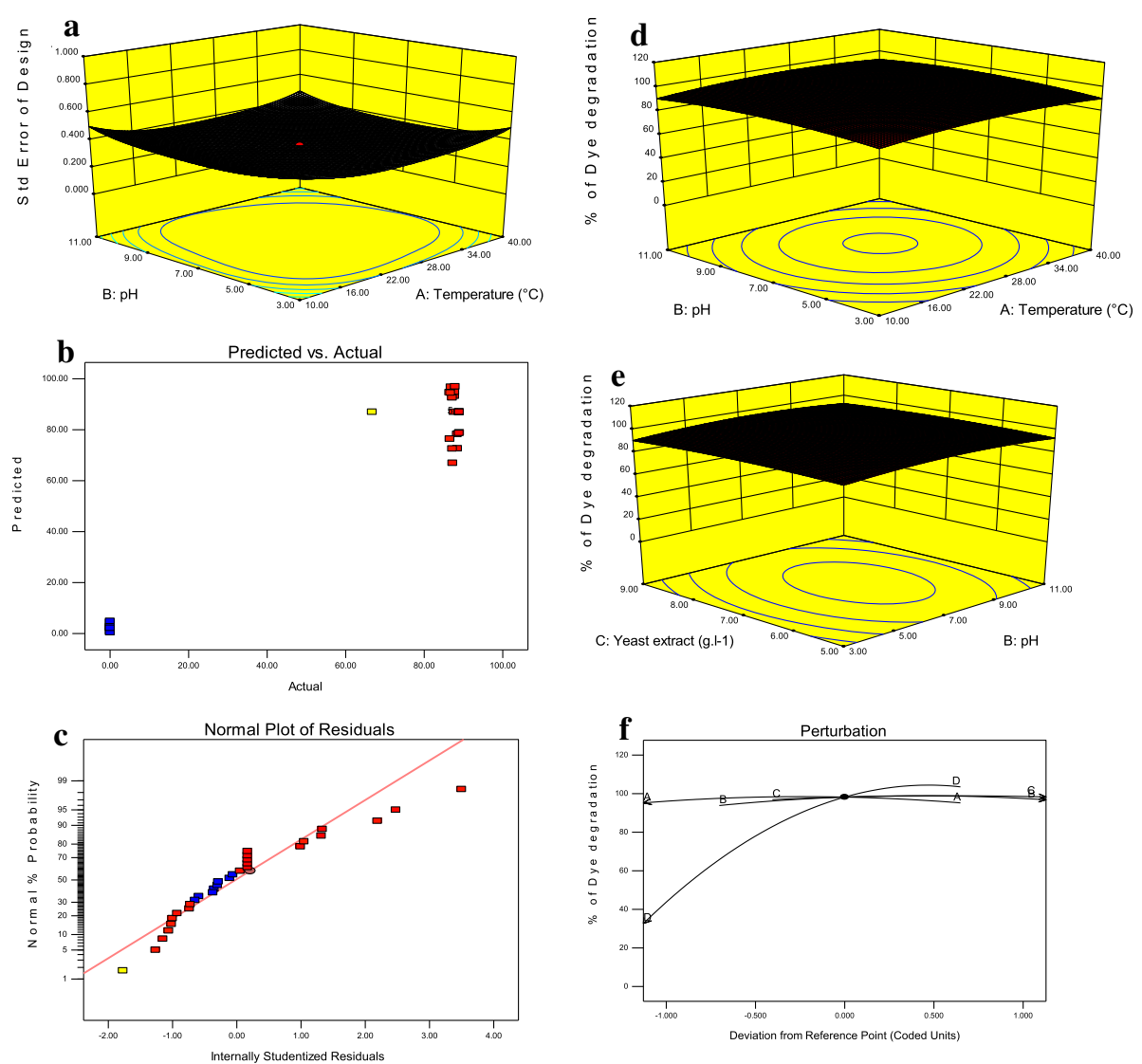

Figure 2 Effect of culture conditions on dye degradation (a) standard error plot for the response of dye degradation and laccase production, (b) predicted and actual response of the dye degradation by Hypocrea lixii, (c) Normal probability, (d) significant interactive effect of $\mathrm{pH}$ and temperature, (e) significant effect of the yeast extract and $\mathrm{pH}$, (f) optimization of the dye degradation of perturbation plot. 


\section{Acute toxicity test}

The acute toxicity was tested according to Mathew's method (Matthews 1995). The methodology of the toxicity test with Artemia salina consisted of exposing them at nauplii (Instar I) stage, hatched freshly in a saline solution $\left(34 \mathrm{~g} \mathrm{~L}^{-1}\right)$, to the different concentrations of the dye before and after biodegradation, for a period of $24 \mathrm{~h}$ at $25^{\circ} \mathrm{C}$. The degraded and non degraded dye solution was tested in different concentrations of 100 , $75,50,33.3,25,16.6,4.2$ and 2.08\%. Negative controls were carried out in parallel using only a synthetic marine salt solution. After $24 \mathrm{~h}$ of incubation, the number of dead larvae was counted and calculated percentage of the mortality.

\section{Results}

Statistical optimization of the factors

The effects of the different levels of the temperature, $\mathrm{pH}$, yeast extract and incubation period on the dye degradation and laccase production by Hypocrea lixii was assessed by using a statistical model. The significant changes of dye decolouration are observed in Figure $1 \mathrm{a}$ and $\mathrm{b}$.

\section{Analysis of model fitness}

The quadratic model fitness and acceptance was assessed based on the statistical significance and lack of fit on the response of dye degradation and laccase production. The probability values are shown in Tables 2 and 3 based on Student's T- test and analysis of variance
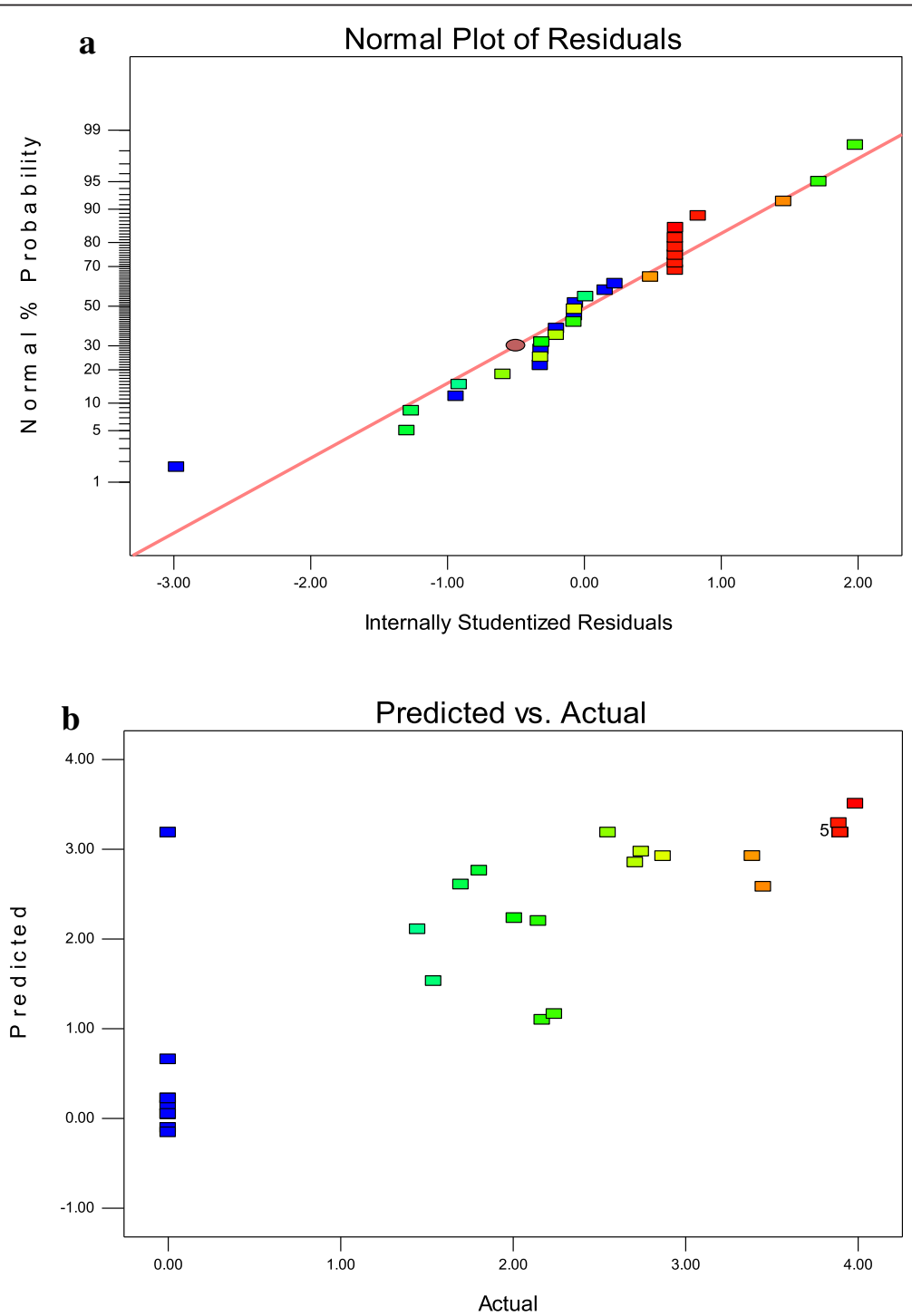

Figure 3 Effect of the factors on laccase production by Hypocrea lixii (a) Normal probability plot for laccase production (b) Regression of predicted and actual response of laccase production by Hypocrea lixii. 
fitted to second order polynomial equation. The probability values of $<0.05$ indicated that the variables were statistically significant. The model was highly significant (F-20.09; P-0.0001; DF-14), and the lack of the fit was not significant (F-2.98; P-0.09; DF-9) for the response of dye degradation (Table 2). In the case of the laccase production the model was significant (F-2.62; P-0.03; DF-14) and also lack of fit was not significant (F-0.34; P-0.92; DF-9) and hence, the quadratic model was valid for the present study. A low value of standard error (0.43) between the measured and model data showed that the equation adequately represented actual relationship between dye degradation and laccase production (Figure 2a). High value of $\mathrm{R}^{2}$ of 0.94 and 0.70 was very close to the predicted value of $R^{2}$ and it indicated a high dependence and correlation between the observed and the predicted values of response of dye degradation and laccase production respectively. The regression equation coefficients were calculated and the data were fit to a second-order polynomial equation. The response, dye degradation (Y1) and laccase production (Y2) by Hypocrea lixii is expressed in terms of the following regression equation:

$$
\begin{aligned}
\text { Y1 (Dye degradation })= & 86.98+1.06 \mathrm{X}_{1}+0.93 \mathrm{X}_{2} \\
& -0.054 \mathrm{X}_{3}+46.13 \mathrm{X}_{4}-4.11 \mathrm{X}_{1}^{2} \\
& -4.07 \mathrm{X}_{2}^{2}-2.05 \mathrm{X}_{3}^{2}-28.08 \mathrm{X}_{4}^{2} \\
& +0.10 \mathrm{X}_{1} \mathrm{X}_{2}+0.13 \mathrm{X} 1 \mathrm{X} 3 \\
& -0.071 \mathrm{X}_{1} \mathrm{X}_{4}+0.071 \mathrm{X}_{2} \mathrm{X}_{3} \\
& +0.050 \mathrm{X}_{2} \mathrm{X}_{4}-0.069 \mathrm{X}_{3} \mathrm{X}_{4}
\end{aligned}
$$
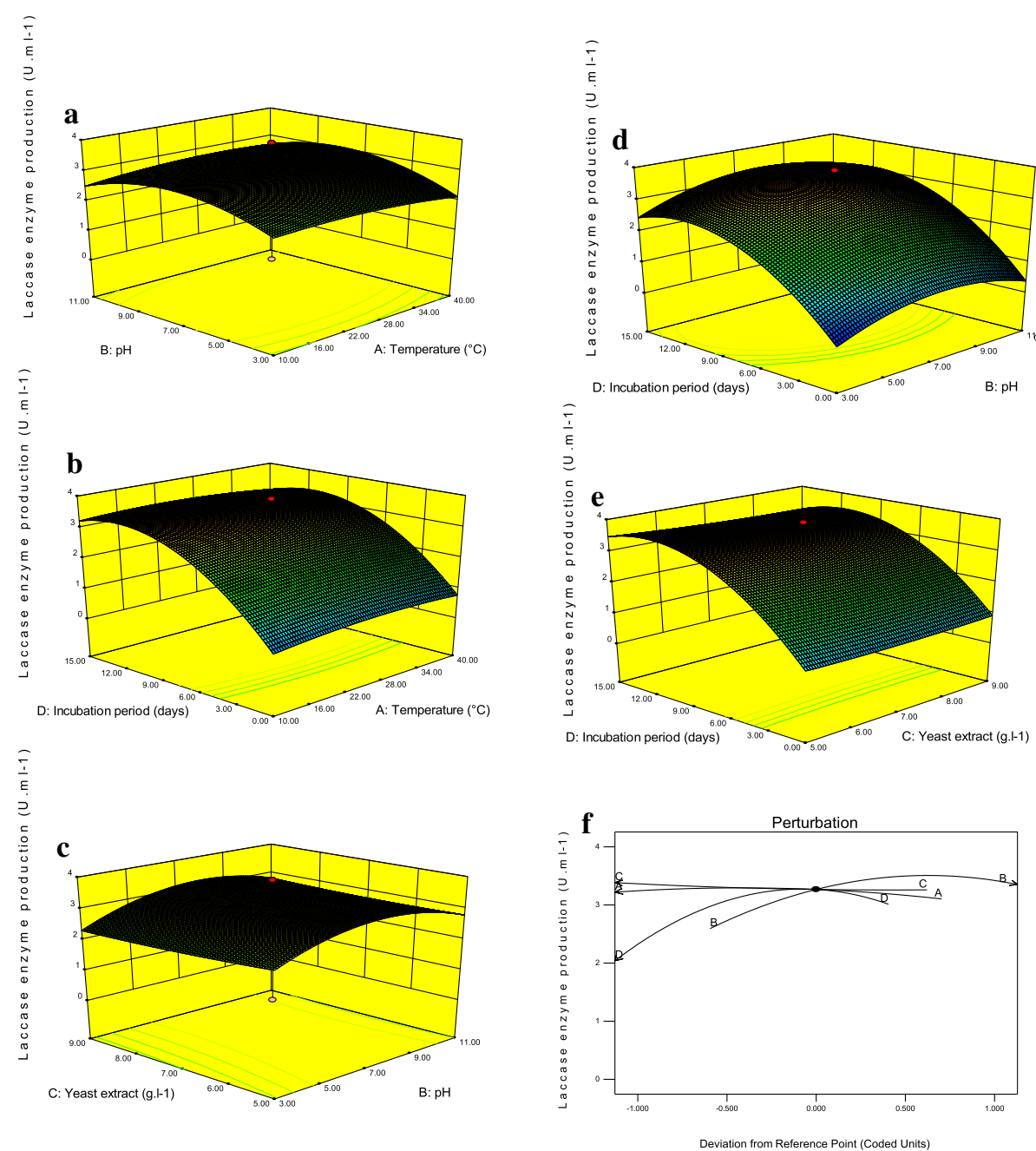

Figure 4 Interactive effect of the culture conditions (a) effect of the $\mathrm{pH}$ and temperature, (b) effect of incubation period and temperature, (c) effect of yeast extract and $\mathrm{pH}$, (d) effect of the incubation period and $\mathrm{pH}$, (e) effect of the incubation period and yeast extract on laccase production, and (f) optimization of the laccase production of perturbation plot. 


$$
\begin{aligned}
\mathrm{Y} 2 \text { (laccase })= & 3.19-2.97 \mathrm{X}_{1}+0.18 \mathrm{X}_{2}-0.054 \mathrm{X}_{3} \\
& +1.22 \mathrm{X}_{4}-0.15 \mathrm{X}_{1}^{2}-0.61 \mathrm{X}_{2}^{2}+0.053 \mathrm{X}_{3}^{2} \\
& -1.12 \mathrm{X}_{4}^{2}+0.10 \mathrm{X}_{1} \mathrm{X}_{2}+0.13 \mathrm{X} 1 \mathrm{X} 3 \\
& -0.073 \mathrm{X}_{1} \mathrm{X}_{4}+0.071 \mathrm{X}_{2} \mathrm{X}_{3}+0.050 \mathrm{X}_{2} \mathrm{X}_{4} \\
& -0.069 \mathrm{X}_{3} \mathrm{X}_{4}
\end{aligned}
$$

Whereas: $\mathrm{X}_{1}$ is temperature $\mathrm{X}_{2}$ is $\mathrm{pH} \mathrm{X}_{3}$ is yeast extract and $\mathrm{X}_{4}$ is incubation period.

Further confirmation of the experimental model for the dye degradation was tested by plotting the normal probability and predicted and observed response of the dye degradation (Figure $2 \mathrm{~b}$ and $\mathrm{c}$ ). The regression analysis of the optimization study indicated that the model terms, $\mathrm{X}_{2}, \mathrm{X}_{4}, \mathrm{X}_{4}^{2}, \mathrm{X}_{1} \mathrm{X}_{2}$ and $\mathrm{X}_{2} \mathrm{X}_{3}$ were significant on dye degradation by Hypocrea lixii $(\mathrm{P}<0.05)$ (Table 2 and Figure $2 \mathrm{~d}$ and e). These results indicated that $\mathrm{pH}$, incubation period and interactions of the factors such as temperature and $\mathrm{pH}$ had the direct association with dye degradation. Lack of fit (0.09) also suggested that the obtained experimental data were of a good fit with the model (Table 2). The optimal conditions for the maximum dye degradation were assessed by using the statistical perturbation plot (Figure 2f). The maximum dye degradation was observed under the optimal conditions: temperature $30^{\circ} \mathrm{C}, \mathrm{pH}$ of 5.8 , yeast extract $5.81 \mathrm{mg} \mathrm{L}^{-1}$ at incubation period of 10 days (Figure 2f).

The confirmation of the experimental setup for the laccase production was attributed by using normal probability, predicted response of analysis (Figure 3a-b). The regression analysis of the optimization study indicated that the model terms, $\mathrm{X}_{1}, \mathrm{X}_{2}, \mathrm{X}_{4}, \mathrm{X}_{2}^{2}$, and $\mathrm{X}_{4}^{2}$ were significant on laccase production by Hypocrea lixii $(\mathrm{P}<0.05)$ (Table 3 and Figure 4a-e). These results indicated that temperature, $\mathrm{pH}$, incubation period had the direct association with laccase production. Lack of fit (0.92) also suggested that the obtained experimental data were of a good fit with the model (Table 3). The optimal conditions of the laccase production by the Hypocrea lixii was assessed by using a perturbation plot (Figure 4f). Statistically

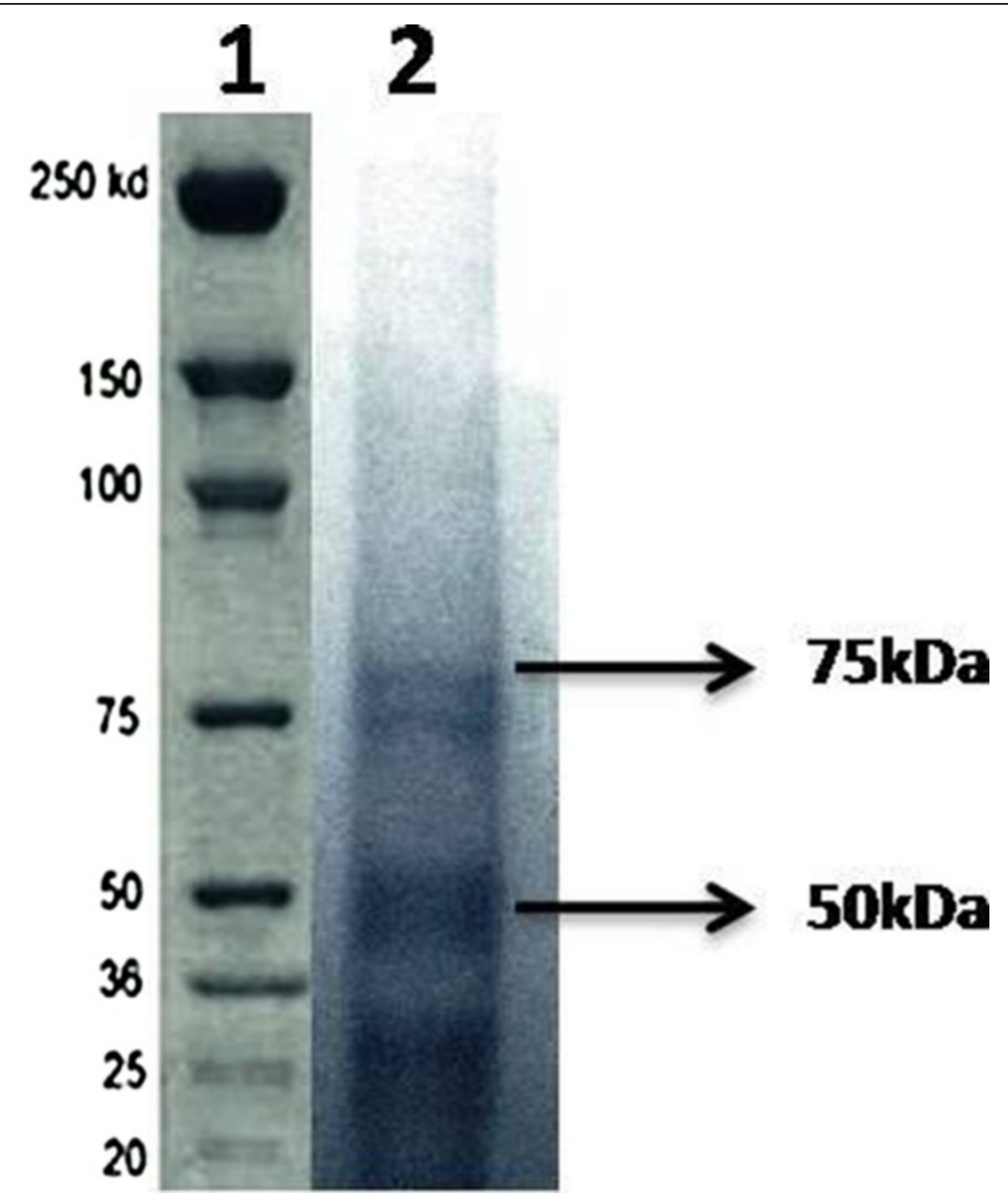

Figure 5 SDS-PAGE patterns of purified laccaseof $\boldsymbol{H}$. lixii culture extract. (SDS-PAGE carried out using 5\% polyacrylamide gel containing $0.1 \%$ SDS, and stained with $0.1 \%$ Coomassie brilliant blue R-250 after electrophoresis. Lane 1- Marker, molecular weight marker; lane 2 - Laccase from $H$. lixii). 
optimized conditions for the maximum laccase production was observed at the temperature of $29^{\circ} \mathrm{C}, \mathrm{pH}$ of 5.3 , yeast extract of 7.7 and incubation period of 12 days (Figure 4f).

\section{Molecular weight of laccase}

The overall yield of the purification was around $58 \%$, with a purification of 11.4 fold and a specific enzyme activity of $3.2 \mathrm{Umg}^{-1}$. The partially purified enzyme showed a single band after SDS-PAGE (Figure 5). The molecular mass of purified laccases was found to be approximately $50 \mathrm{kDa}$ and $75 \mathrm{kDa}$, as determined by SDS-PAGE.

\section{FT-IR (Fourier Transform Infra Red) studies}

In order to confirm the degradation of malachite green by Hypocrea lixii, the dye solution was subjected to FT-IR spectral analysis, before and after degradation. The FT-IR spectra of degraded dye and undegraded dye are shown in Figure $6 \mathrm{a}$ and $\mathrm{b}$. FT-IR spectra of undegraded dye showed the specific peaks in a range between 1500 and $500 \mathrm{~cm}^{-1}$ for the mono and para-di substituted benzene rings. The peaks between 400 and $550 \mathrm{~cm}^{-1}$ represented the presence of sulphide groups and bromine groups. Also the peak at $1128.36 \mathrm{~cm}^{-1}$ for the $\mathrm{C}-\mathrm{N}$ stretching vibrations and peak at $2931 \mathrm{~cm}^{-1}$ for $\mathrm{C}-\mathrm{H}$ stretching of asymmetric $-\mathrm{CH}_{3}$ group provided the perception of structure of malachite green. The degraded dye revealed an overall reduction in the spectra and both mono and para-di substituted benzene rings, sulphates and $-\mathrm{CH}_{3}, \mathrm{O}-\mathrm{H}, \mathrm{N}-\mathrm{H}$, and $\mathrm{C} \equiv \mathrm{N}$ groups. The peak reduction was attributed to the cleavage of synthetic dye bonds. The dye got completely degraded after 10 days of incubation.

\section{Scanning electron microscopic (SEM) studies}

Purpose of knowing the changes before and after accumulation of the dye in surface area of Hypocrea lixii biomass was studied by using SEM (Figure 7a-b). Significant
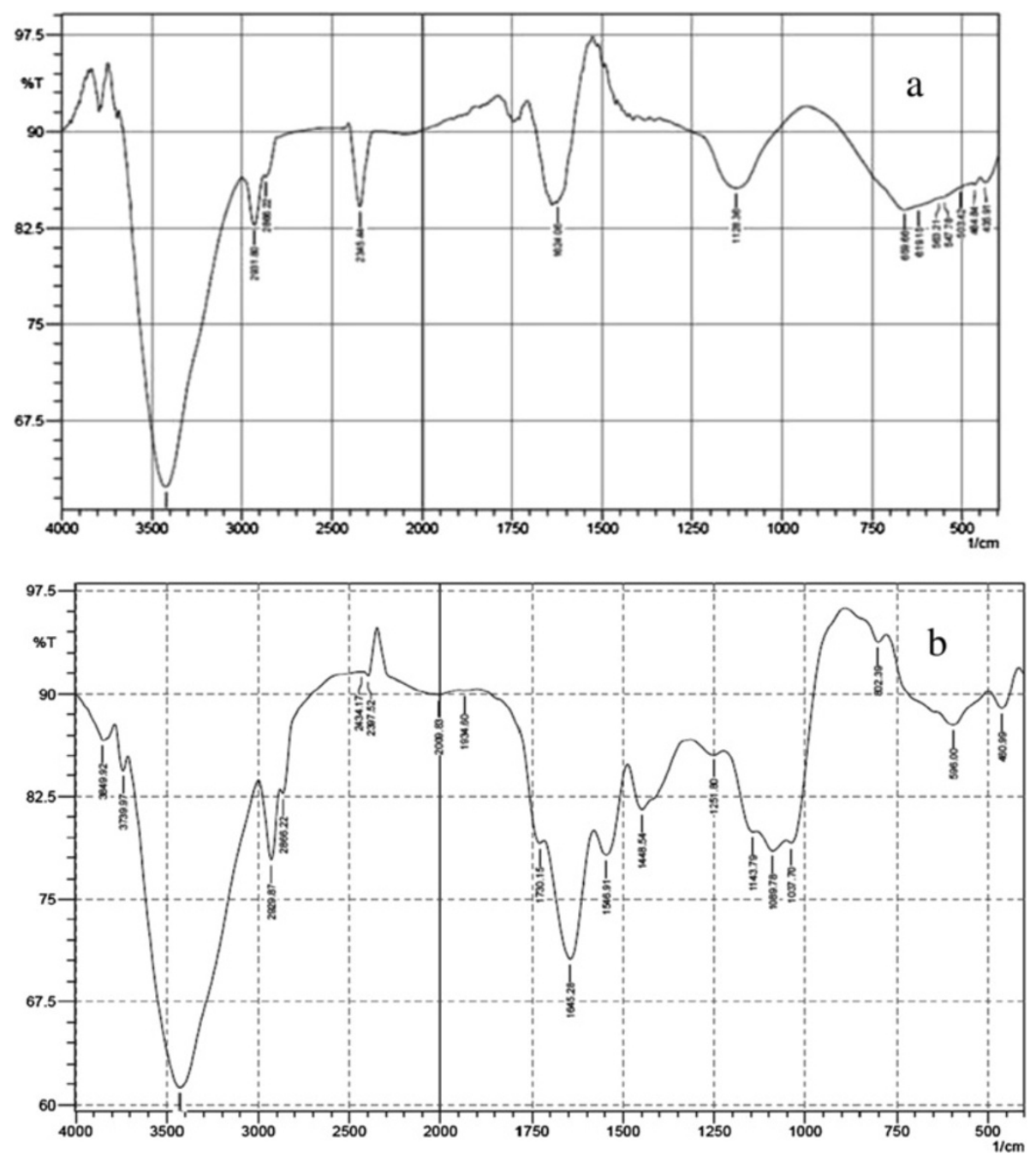

Figure 6 FT-IR representation of dye degradation (a) before dye degradation (b) after dye degradation. 
changes were observed on the surface of microbial biomass after dye accumulation by Hypocrea lixii (Figure 7b). In the non- dye treated control, fungal spores were distinct, but in dye treated, the fungal spores were not clearly visible.

\section{Biotoxicity}

The toxicity of degraded and undegraded dye solutions was tested with Artemia salina and the results are presented in Figure 8 . The mortality was observed $100 \%$ in the undegraded dye solution as against only $2-5 \%$ in degraded dye solution (Figure 8).

\section{Discussion}

The present work showed the significant effect of the marine fungal strains Hypocrea lixii on dye degradation and laccase production (Figure $1 \mathrm{a}$ and $\mathrm{b}$ ). This finds support of earlier workers who have demonstrated similar finding of dye degradation with spore forming fungal strains of the Trichoderma harzianum/Hypocrea lixii and Aspergillus flavus, Fusarium oxysporum and F. moniliforme for the textile dye degradation and enzyme production (Raju et al. 2007; Rajalakshmi and Sudha 2011; Kathiresan et al. 2011; Saravanakumar and Kathiresan 2012). Trichoderma harzianum/Hypocrea lixii (TSK8) has been improved mangroves plants growth (Saravanakumar et al.
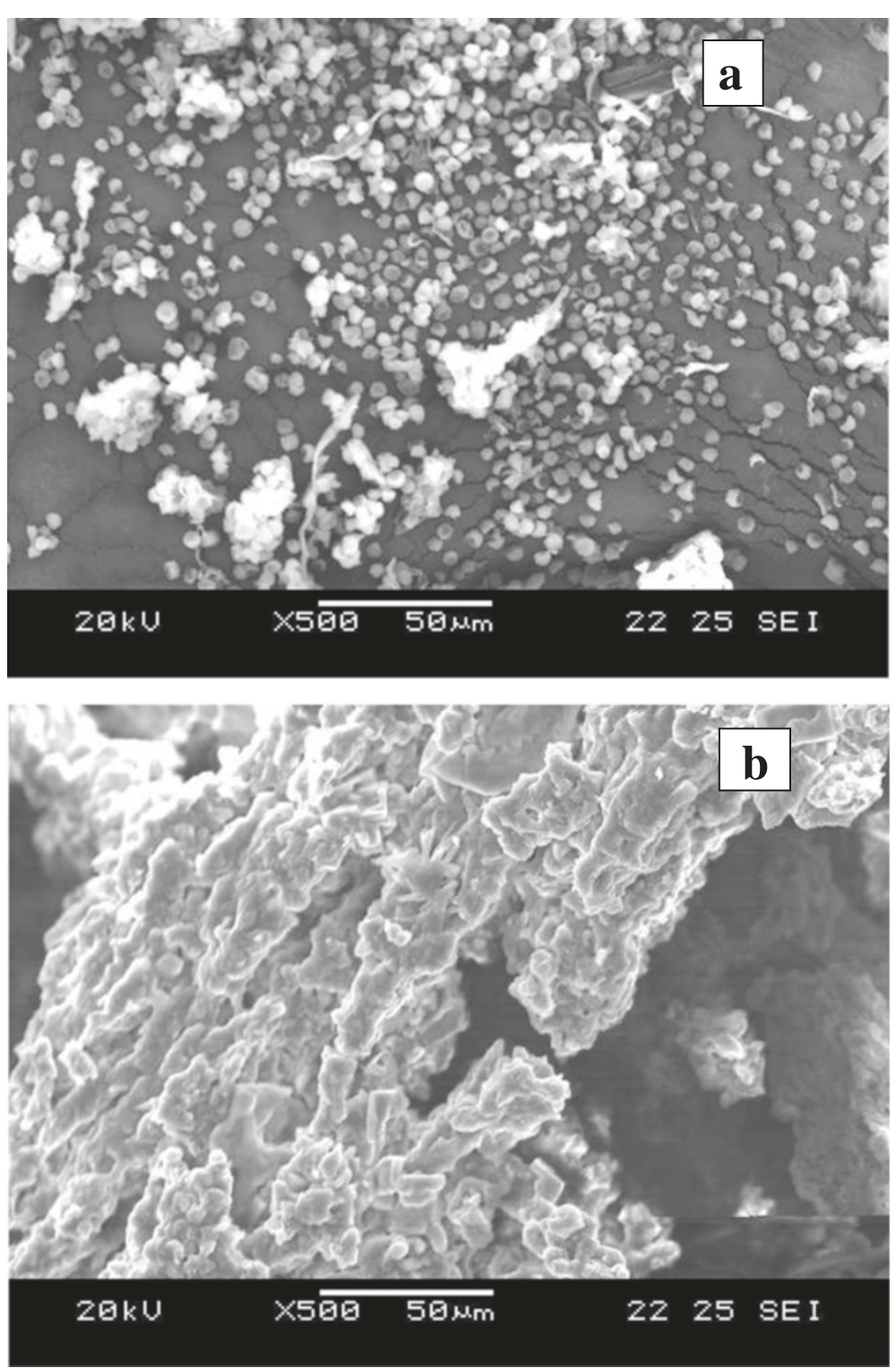

Figure 7 Scanning electron microscopic representation of the dye degradation (a) Control untreated Hypocrea lixii spores (50 $\mu \mathrm{m}$ ), (b) dye treated Hypocrea lixii spores $(50 \mu \mathrm{m})$. 


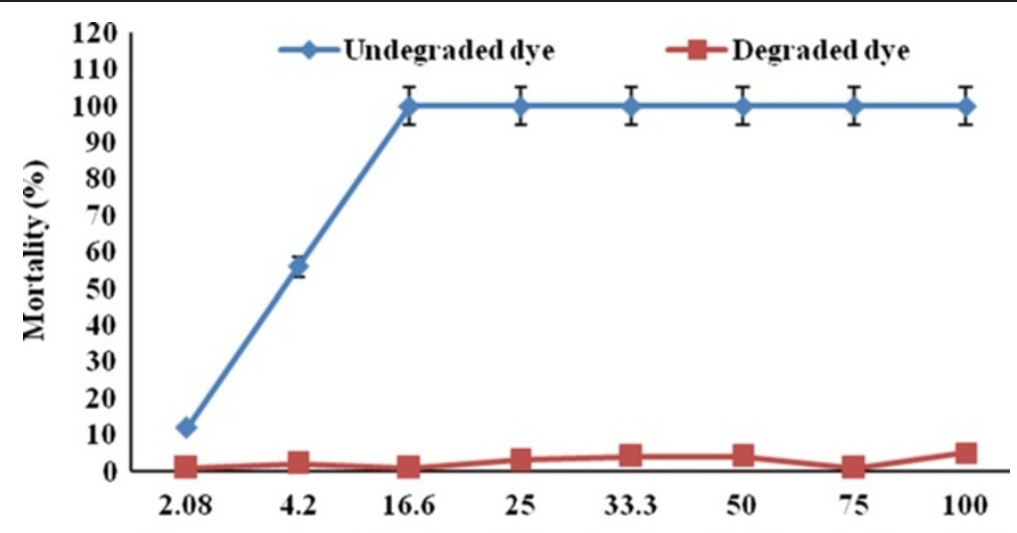

Concentration of the degraded and undegraded dye solution $\left(\mathrm{ml} . \mathrm{I}^{-1}\right)$

Figure 8 Effect of toxicity of degraded and undegraded dye solution on Artemia salina culture.

2013) Laccase producing micro organisms are potent source for the degradation of the textile dye (Tavares et al. 2008). Dye decolourization by fungi during growth on solid medium has been widely employed to identify the ligninolytic potential and potential degradation of phenolic compounds (Wesenberg et al. 2003; Rajalakshmi and Sudha 2011). The laccase produced by Hypocrea lixii exhibited the molecular weight of the 50 and $75 \mathrm{kDa}$, similar to those reported for laccases produced by Aspergillus sp. (Youshuang et al. 2011).

The present study achieved $89 \%$ degradation of synthetic dye Malachite Green by Hypocrea lixii under the optimal conditions of temperature $30^{\circ} \mathrm{C}, \mathrm{pH}$ of 5.8 , yeast extract $5.81 \mathrm{mg} .1^{-1}$ at incubation period of 10 days (Figure 2f). The dye degradation was significant with increased laccase in the solution. In the present study the maximum activity of laccase was observed on the $12^{\text {th }}$ day and confirmed that $100 \%$ of dye was removed by laccase produced by Hypocrea lixii on the $12^{\text {th }}$ day of the degradation process. This report is in conformity with previous researchers (Ambrosio and Takaki 2004; Machii et al. 2004).

FTIR spectra confirmed the degradation of Malachite Green in the solution, as evident by the appearance of some new peaks and absence of important peaks required for structural integrity of the dyes. In the case of UV-vis absorption spectra, there was a complete disappearance of major visible light absorbance peaks (Figures $1 \mathrm{~b}$ and $6 \mathrm{a}, \mathrm{b})$. A similar report has been made with methyl red degradation by Sphingomonas paucimobilis (Ayed et al. 2011). Scanning electron microscopic observations also confirmed the accumulation of the malachite green on the surface of the fungal biomass. The degraded dye showed low toxicity to artemia larvae. Thus the dye after degradation by Hypocrea lixii, if discharged to aquatic environments, may not cause any damage to the aquatic animals. Thus the laccase producing Hypocrea lixii is a promising fungal strain for degradation of synthetic dye.

\section{Competing interests}

The authors declare that they have no competing interests.

\section{Authors' contribution}

KS \& KK Designed and carry out the experiments and participated in statistical analysis and drafted the manuscript. Both authors read and approved the final manuscript.

\section{Acknowledgements}

The authors are thankful to the authorities of Annamalai University for providing facilities.

Received: 10 June 2014 Accepted: 16 October 2014

Published: 25 October 2014

\section{References}

Akar T, Ozkara E, Celik S, Turkyilmaz S, Akar ST (2013) Chemical modification of a plant origin biomass using cationic surfactant ABDAC and the biosorptiv decolorization of RR45 containing solutions. Colloids Surf B Biointerface 101(1):307-331

Ambrosio ST, Takaki GMC (2004) Decolorization of reactive azo dyes by Cunninghamella elegans UCP 542 under co-metabolic conditions. Biores Technol 91:69-75

Anjaneyulu Y, Chary NS, Raj DSS (2005) Decolorization of industrial effluents available methods and emerging technologies. Environ Sci Biotechnol 4:245-273

Ayed L, Achour S, Khelifi E, Cheref A, Bakhrouf A (2010) Use of active consortia of constructed ternary bacterial cultures via mixture design for Congo Red decolorization enhancement. Chem Eng J 162:495-502

Ayed L, Bakhrouf A, Achour S (2011) Application of the mixture design to decolorize effluent textile wastewater using continuous stirred bed reactor. Water SA 37:21-26

Baldeva E, Mubarak Ali D, llavarasi A, Pandiaraj D, Sheik Syed Ishackc KA, Thajuddin N (2013) Degradation of synthetic dye, Rhodamine B to environmentally non-toxic products using microalgae. Colloids Surf B Biointerfaces http://dx.doi.org/10.1016/j.colsurfb.2013.01.008

Box GEP, Behnken DW (1960) Three level design for the study of quantitative variables. Technometrics 2:455-475

Casas N, Blanquez P, Gabarrell X, Vicent T, Caminal G, Sarra M (2007) Degradation of orange $G$ by laccase: Fungal versus enzymatic process. Environ Technol 28:1103-1110

Claus H (2003) Laccases and their occurrence in prokaryotes. Arch Microbiol 179:145-150

Deng S, Gang Y, Ting YP (2005) Production of a bioflocculant by Aspergillus parasiticus and its application in dye removal. Colloids Surf B Biointerface 44(4):179-186 

dyeing of cotton. Biotechnol Lett 28:755-759

Kathiresan K, Saravanakumar K, Anburaj R, Gomathi V, Abirami G, Sahu SK, Anandhan S (2011) Microbial enzyme activity in decomposing leaves of mangroves. Int J Adv Biotechnol Res 2(3):382-389

Lowry OH, Rosebrough NS, Farrand AL, Randal RJ (1951) Protein measurement with folin phenol reagent. J Biol Chem 193:263-275

Machii Y, Hirai H, Nishida T (2004) Lignin peroxidase is involved in the biobleaching of manganese-less oxygen-delignified hardwood kraft pulp by white-rot fungi in the solid-fermentation system. FEMS Microbiol Lett 233:283-287

Matthews RS (1995) Artemia salina as a test organism for measuring superoxidemediated toxicity. Free Radic Biol Med 18(5):919-922

Mayer AM, Staples RC (2002) Laccase: new functions for an old enzyme. Phytochemistry 60:551-565

McMullan G, Meehan C, Conneely A, Kirby N, Robinson T, Nigam P, Banat I, Marchant R, Smyth W (2001) Microbial decolourisation and degradation of textile dyes. Appl Microbiol Biotechnol 56:81-87

Niladevi KN, Prema P (2008) Effect of inducers and process parameters on laccase production by Streptomyces psammoticus and its application in dye decolorization. Biores Technol 99:4583-4589

Peralta-Hernandez JM, Carlos A, Martínez-Huitle Jorge L, Guzmán M, HernandezRamirez A (2009) Recent advances in the application of electro-fenton and photoelectro-fenton process for removal of synthetic dyes in wastewater treatment. J Environ Eng Manag 19(5):257-265

Rajalakshmi G, Sudha S (2011) Decolourisation of methyl orange and methyl red by live and dead biomass of fungi. Asian J Exp Biol Sci 2(4):569

Raju NS, Venkataramana GV, Girish ST, Raghavendra VB, Shivashankar P (2007) Isolation and evaluation of indigenous soil fungi for decolourization of textile dyes. J Appl Sci 7:298-301

Robinson T, McMullan G, Marchant R, Nigam P (2001) Remediation of dyes in textileeffluent: a critical review on current treatment technologies with a proposedalternative. Bioresour Technol 77:247-255

Saparrat M, Hammer E (2006) Decolorization of synthetic dyes by the deuteromycetePestalotiopsis guepinii CLPS no. 786 strain. J Basic Microb 46:28-33

Saravanakumar K, Kathiresan K (2012) Statistical optimization of protease production by mangrove-derived Trichoderma estonicum and its potential on blood stain removal. Int J Biotech Mol Biogeosci 3(2):15-21

Saravanakumar K, Shanmuga Arasu V, Kathiresan K (2013) Effect of Trichoderma species on Avicennia marina. Aquat Bot 104:101-105

Tavares APM, Cristovao RO, Loureiro JM, Boaventura RAR, Macedo EA (2008) Optimisation of reactive textile dyes degradation by laccase-mediator system. J Chem Technol Biotechnol 99:311-323

Telke AA, Kalyani DC, Jadhav UU, Parshetti GK, Govindwar SP (2009) Purification and characterization of an extracellular laccase from a Pseudomonas SP. LBC1 and its application for the removal of bisphenol A. J Mol Catal B Enzym 61:252-260

Wesenberg D, Kyriakides I, Agathos SN (2003) White-rot fungi and their enzymes for the treatment of industrial dye effluents. Biotechnol Adv 22:161-187

Xiangkang Z, Yujie C, Xiangru L, Xianglong Z, Wenxiu L, Dabing Z (2011) Decolorization of synthetic dyes by crude laccase from a newly isolated Trametes trogii strain cultivated on solid agro-industrial residue. J Hazard Mater 187:517-525

Youshuang Z, Haibo Z, Mingle C, Zhenzhen M, Feng HE, Peiji G (2011) Production of a thermostable metal-tolerant Laccase from Trametes versicolor and its Application in dye decolorization. Biotechnol Bioprocess Eng 16:1027-1035

Zhang GQ, Wang YF, Zhang XQ, Ng TB, Wang HX (2010) Purification and characterization of a novel laccase from the edible mushroom Clitocybe maxima. Process Biochem 45:627-633

Zhu Y, Yinglong Z, Haibo Z, Feng $H$ (2011) The effect of laccase on cellulasetreated lignin in 1-n-butyl-3-methylimidazolium chloride/ $\mathrm{H}_{2} \mathrm{O}$ homogeneous and $\mathrm{H}_{2} \mathrm{O}$ heterogeneous solutions. Afr J Biotechnol 10(69):15647-15655

doi:10.1186/2193-1801-3-631

Cite this article as: Saravanakumar and Kathiresan: Bioremoval of the synthetic dye malachite green by marine Trichoderma sp. SpringerPlus 2014 3:631

\section{Submit your manuscript to a SpringerOpen ${ }^{\circ}$ journal and benefit from:}

- Convenient online submission

- Rigorous peer review

- Immediate publication on acceptance

- Open access: articles freely available online

- High visibility within the field

- Retaining the copyright to your article 